
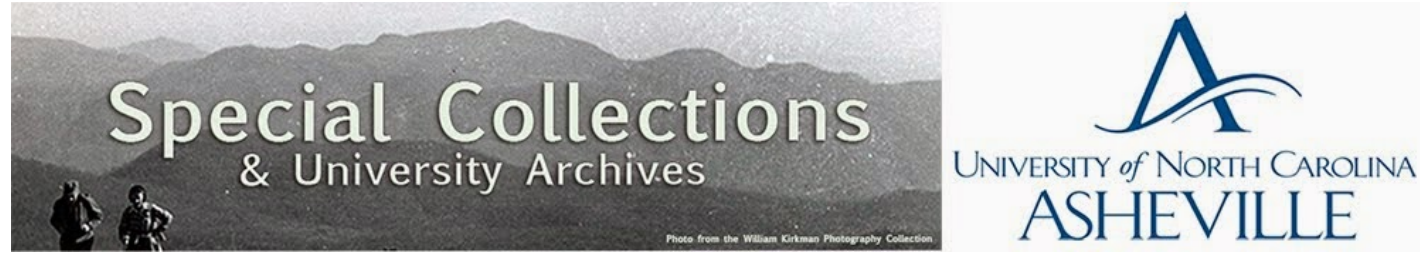

Archived faculty publication from the University of North Carolina at Asheville's NC DOCKS Institutional Repository: http://libres.uncg.edu/ir/unca/

Locklear, Erica Abrams. "On Teaching Harriette Simpson Arnow." Appalachian Heritage, 40 no. 2 (Spring 2012): 53-55. 


\section{ON TEACHING HARRIETTE SIMPSON ARNOW}

\section{Erica Abrams Locklear}

When I began doctoral study in English at Louisiana State University in 2003, I thought I knew a little something about Appalachian literature. I had read James Still, Lee Smith, Robert Morgan, and several other mountain writers, and I was vaguely familiar with a handful of other related sources, like Joyce Dyer's collection, Bloodroot: Reflections on Place by Appalachian Women Writers. Then I took a Southern literature seminar with John Lowe who, during one of our conversations about Appalachian literature, offhandedly remarked that he really loved Harriette Simpson Arnow's The Dollmaker. Before that day, I had never heard of Arnow or any of her works. Looking back on that conversation now, I wonder how this was possible.

After my class ended, I read The Dollmaker and was astounded. I remember being completely enthralled by the story in general, but more particularly I admired Gertie's perseverance, empathized with Reuben and Cassie's longing to return home, loathed Mrs. Whittle's treatment of Reuben, and wanted to think more deeply about how Arnow portrayed the identity conflicts that ensued after the family moved to Detroit. I decided to write about it in my dissertation, and later in my first book. I was similarly moved by Arnow's other novels, especially Hunter's Horn. As I learned more about her work, I became increasingly confused as to why she is now read so infrequently by academics, students, and mainstream readers. Upon further investigation, I learned that The Dollmaker won wide critical acclaim during its time and was nominated for the National Book Award in 1955, losing to William Faulkner's The Fable (Eckley 44). Twenty-three years later, in 1978, Tillie Olsen lamented that, as a woman's "book of great worth, [The Dollmaker suffers] the death of being unknown, or at best a peculiar eclipsing" (40). Considering that the novel tells a powerful story about Appalachian out-migration and the consequences of moving from an agrarian society to an industrial one, all while dealing with issues related to education, gender, and so much more, the "eclipsing" Olsen notes is peculiar, indeed.

When I talk about Arnow's work with fellow academics, I often hear similar explanations of why they have chosen not to teach her work in 
their courses. They usually tell me that while they applaud novels like The Dollmaker, teaching such a long work of fiction seems overwhelming at best and impossible at worst. But in this brief contribution to a longer reflection on Arnow, I want to contest that belief and argue for the inclusion of novels like The Dollmaker on course syllabi for undergraduate and graduate students alike.

Certainly The Dollmaker would make a great novel selection for a course on American or Appalachian literature, as it would for a class that explores issues of migration, industrialization, unionization, and labor struggles in general. But here I want to make a case that The Dollmaker is also an ideal candidate for Women's Studies courses, particularly those that rely on literature to broaden student understandings of women's lives and experiences. In 2009 I taught a special topics course at UNC Asheville called Working Women. In it, we explored real and fictional narratives that contained depictions of women's labor, and students interviewed women in the community so that they could examine how their interviewees' stories did or did not align with those that we spent the semester reading. Early in the course, students responded well to Harriet Jacobs' slave narrative, to Tillie Olsen's Yonnondio: A Novel of the Thirties, and to other texts, but I was nervous about introducing The Dollmaker. Were they really going to read a six-hundred-plus page novel? I was not sure.

To my surprise, the book was a splendid success, generating some of our best class discussions of the semester. When we encountered The Dollmaker, we had already talked about socially constructed gender roles and the often repressive reality of subscribing to gender binaries. Right away, students noticed Gertie's resistance to these limitations, and together we cheered her refusal to adhere to society's expectations of her. Likewise, we had meaningful conversations about why Gertie follows her mother's biblically supported advice to follow Clovis to Detroit, instead of remaining in Kentucky on the farm that she purchased for the family with her own money. By the novel's end, students agreed that one of Gertie's greatest downfalls was her ultimate submission to these gender conventions, reasoning that her subservience catalyzed a long, unfortunate chain of events for the Nevels family. Not surprisingly, students discovered similar threads in their interview transcripts from women in the community, leading to further discussions about life circumstances that can foster such submissiveness.

When I selected The Dollmaker for that course, I did so because it has so much to do with women's labor, but during our discussions about it, I 
began to see the novel in yet another exciting way. I suspect that depending on a course's goals and the students who are in it, conversations about the novel will vary widely, each producing ample material for students and professors alike to explore. I was heartened that several of my students bought copies of the novel to share with their mothers, sisters, and friends, and I look forward to teaching it again in the future.

\section{WORKS CITED}

Eckley, Wilton. Harriette Arnow. New York: Twayne Publishers, Inc, 1974.

Olsen, Tillie. Silences. New York: Delacorte Press/Seymour Lawrence, 1978. 